\title{
CROWD BEHAVIOURAL ANALYSIS AT A MASS GATHERING EVENT
}

\section{ANALIZA ZACHOWAŃ TLUMU W MASOWYCH ZGROMADZENIACH}

\author{
Poojari Yugendar, K.V.R. Ravishankar
}

Narodowy Instytut Technologii Warangal, Telangana State, India, National Institute of Technology Warangal, Telangana State, India,

\begin{abstract}
Religious occasions, gathering at fairs and terminals, are the events of crowd gatherings. Such gatherings act as severe threats for crowds because of high density in less space, which ends up in adverse outcomes resulting in crowd stampedes. The movement of an individual person in a crowd is influenced by the physical factors. In the present study, characteristics like age, gender, group size, child holding, child carrying, people with luggage and without luggage are considered for crowd behaviour analysis. The average speed of the crowd movement was observed as $0.86 \mathrm{~m} / \mathrm{s}$. The statistical analysis concluded that there was a significant effect of age, gender, density and luggage on the crowd walking speed. Multi-linear regression (MLR) model was developed between crowd speed and significant factors observed from the statistical analysis. Location 1 data was used for the model development. This developed model was validated using Location 2 data. Gender has more significant effect on speed followed by luggage and age. This study helps in proper dispersal of crowd in a planned manner to that of diversified directional flow that exist during crowd gathering events.
\end{abstract}

Keywords: Age; Crowd; Gender; Group; Luggage; Speed.

Streszczenie: Uroczystości religijne, targi czy zbiorowiska ludzkie na terminalach sa przykladami masowych zgromadzeń. Stanowia one istotne zagrożenie dla tlumu ze względu na duże zagesszczenie ludzi na mniejszej przestrzeni, które przynosi negatywne efekty $w$ postaci wzajemnego tratowania się. Na ruch poszczególnych osób w tlumie wptywaja czynniki fizyczne. Analiza zachowań tlumu przedstawiona w niniejszym opracowaniu uwzględnia takie cechy jak wiek, pteć, wielkość grupy, trzymanie dziecka, niesienie dziecka, bagaż lub jego brak. Zaobserwowana średnia prędkość poruszania się tłumu wyniosła $0,86 \mathrm{~m} / \mathrm{s}$. Analiza statystyczna wykazała, że znaczacy wplyw na prędkość, z jaka idzie tlum, miaty wiek pteć, gestość oraz bagaż. Model regresji wielolorakiej (MLR) został opracowany dla ujęcia zwiazku pomiędzy prędkościa a istotnymi czynnikami zaobserwowanymi $w$ analizie statystycznej. Do opracowania modelu wykorzystano dane $z$ lokalizacji 1. Opracowany model zostat zwalidowany z wykorzystaniem danych z lokalizacji 2. Płeć ma większy wpływ na prędkość niż odpowiednio bagaż oraz wiek. Niniejsze opracowanie pomaga we właściwym rozpraszaniu thumu w zaplanowany sposób dostosowany do zróżnicowanego przeptywu kierunkowego charakterystycznego dla masowych zgromadzeń.

Stowa kluczowe: wiek; tlum; pteć; grupa; bagaż; prędkość 
Crowd behavioural analysis at a mass gathering event

Analiza zachowań tlumu w masowych zgromadzeniach

\section{CROWD BEHAVIOURAL ANALYSIS AT A MASS GATHERING EVENT}

\section{Introduction}

Crowd is defined as "a large group of individuals in the same physical environment, sharing a common goal" (Musse et al. (1997). Developing countries are more vulnerable to stampedes during mass gathering events, with higher fatality rate than rest of the world [2]. Systems and standards of construction in developing countries are ineffective in practice. Prassana Kumar et al. (2015) stated that on an average more than 70 people per year lost their lives due to stampedes in India. Indian states of Maharashtra and Andhra Pradesh are in top the list of more than 300 deaths in the 15 years (2001-15). According to the motion of crowd, crowd scenes can be divided into two categories: structured, and unstructured. In structured crowded scenes, the crowd moves systematically in common direction, and the flow path does not vary frequently. Whereas, unstructured crowded scenes, people move in different or random directions at different times. Crowd analysis is classified into three types: crowd detection or density estimation models, tracking in crowded scenes, and crowd behaviour understanding models. There are several models to detect people in crowded scenarios which are done by computer vision techniques; these include pixel-based analysis, texture-based analysis, and object-level analysis. Pixel-based analysis is based on background subtraction or edge detection models to determine the density of the crowd. Texture based analysis mostly used to estimate people count rather than density and it requires the analysis of image patches. Object-level analysis tries to identify individual objects in a scene, but identifying individuals in a single image or a video sequence is mostly feasible in lower density crowds.

Crowd tracking is consisting of identifying the position of the same person in a sequence of frames. The knowledge of individual trajectories in a crowd can be explored to identify main flows of a crowd, or to detect abnormal behaviours. Although there are several approaches for the generic problem of object tracking, clutter and severe partial (or even total) occlusions make individual person tracking a challenging problem in denser crowd. Mehran et al. (2009) proposed two approaches for crowd behaviour analysis, which are object-based approach and holistic-based approach. Object based approach considers a crowd as a collection of individuals. In this method the crowd behaviour is analysed through the detecting the individuals to analyse the group behaviours. In denser scenes it is very difficult to track the individual components in the crowd. This method is applicable to low or moderately crowded scenes. Crowd is treated as a single entity in holistic based approach. This approach tries to obtain information like main crowd flows. This approach ignores the information such as a person moving against the flow. This method is mostly applicable to dense crowded scenes. 


\section{Literature Review}

For the density measurement, object detection technique is used where as for the speed, object tracking technique is used. Crowd behaviour models (object based approach) is used for behaviour analysis of each individual person in the crowd.

\section{Crowd Detection}

Davie et al. (1995) proposed an approach to estimate the crowd density by background subtraction removal technique and edge detection. Ma et al. (2004) developed a method based on the counting of foreground objects on each pixel to estimate the crowd density. Kong et al. (2006) presented a method to estimate the number of people in a crowd. Edge orientation and the histogram object areas are extracted from foreground objects through background subtraction algorithm. Marana et al. (1998) analysed four methods for texture analysis and three classifiers to estimate the crowd density. For texture analysis, they compared four methods (grey level dependence matrix, straight-line segments, fourier analysis and fractal dimension). Wu et al. (2006) proposed an approach to estimate the crowd density using texture analysis and support vector machines. Rahmalan et al. (2006) proposed a comparison of three techniques (gray level dependence matrix, the minkowsk fractal dimension, and translation invariant orthonormal chobyshev moments) in texture analysis to estimate the crowd density. Chan et al. (2008) developed a crowd-counting algorithm based on texture, Gaussian process regression, and motion segmentation techniques. Object level analysis tries to identify individual objects in a scene. Zhao et al. (2003) presented Baysian approach to segment people in crowds. Leibe et al. (2005) developed a pedestrian detection scheme using a top-down segmentation approach.

\section{Crowd Tracking}

Brostow et al. (2006) presented an unsupervised Baysian clustering method to detect independent movements in a crowd. H. Dridi (2009) presented a real-time method for pedestrian recognition and tracking in sequences of high-resolution images obtained by a stationary camera located in different places on the Haram mosque in Mecca.Boghossian et al. (1999) presented an approach to estimate the paths and main directions of a crowd in a CCTV (Closed Circuit Television) using a block-matching algorithm for motion estimation.

\section{Crowd Behaviour Understanding Models}

Jacques et al. (2007) proposed an algorithm for group detection and crowd classification as voluntary or involuntary based on computer vision. Cheriyadat et al. (2008) presented an approach for clustering a set of low-level motion features into trajectories. Rabaud et al. (2006) and Brostow et al. (2006) identified each member in the frame based on motion indication. Wang et al. (2009) presented an unsupervised learning framework to model activities and interactions in crowded and complicated scenes. 
Crowd behavioural analysis at a mass gathering event

Analiza zachowań tlumu w masowych zgromadzeniach

Davies et al. (1995) proposed an approach to distinguish static crowd from moving crowds based on discrete Fourier transform combined with a linear area transform algorithm. Andrade et al. (2006) described a usual behaviour of crowd based on the analysis of their optical flow using Hidden Markov Model (HMMs). Ali and Shah (2007) proposed an approach based on Lagrangian particle dynamics to segment the flow of a crowd to detect the crowd's uncertainty. Kratz and Nishino (2009) presented an approach for anomaly detection in extremely crowded scenes based on the spatiotemporal information. Jun $\mathrm{Hu}$ et al. (2014) proposed a threedimensional cellular automata model with the stair factors. They conducted a simulation to study the relationships of exit width, evacuation time, pedestrian density, as well as average system velocity. Sankaran and Lakshmi (2016) proposed a method for the evaluation of Pedestrian level of service (PLOS) at sidewalk, based on quantitative and qualitative data. Faisel et al. (2013) identified risk factors from the study of past incidents. These risk factors lead to the development of a basic framework aligned on four interlinked compartments for inter-agency cooperation and multi-disciplinary contemplation. Risk factors ranging from hazard identification to the execution of mitigation measures for human stampede risk reduction. Gayathri et al. (2017) presented an exhaustive review of the current understanding of crowd dynamics and explores the modelling techniques that are available to enhance crowd safety.

From the literature review, many researchers have focussed on crowd density estimation, crowd tracking, and crowd behaviour analysis based on holistic approach. Most of the studies are conducted in indoor conditions and the limited studies carried out in outdoor conditions. There is a need to conduct research on object-based approach in outdoor condition. The present study aims to analyse the effect of gender, age group, group size, child carrying, child holding and people with and without luggage on crowd behaviour. In the present study, flow and density are estimated by pixel-based analysis and speed by using tracker software. The next section describes the methodology and study area details, and in the subsequent section results are discussed.

\section{Study Area}

In this study, locations are selected to observe different flow patterns of the crowd. The behaviour of each person in a crowd is affected by their surrounding person movement. Location-1 is a three-legged intersection which is located near temple entrance. The crowd movement is diversified at this location because of crowd merging from three directions to temple entrance. Location 2 is a mid-block section located between temple and bus stand. The crowd movement is directional but not proper planned manner at this location because of roadside vendors and shops. Two crowded locations during sammakka-saralamma festival in Medaram, Warangal city, Telangana were selected for the study. This event was held during $17^{\text {th }}$ to $20^{\text {th }}$ February 2016. Sammakka-Sarakka festival is a Hindu largest tribal congregation in the world and second largest in India after Kumbha Mela (120 million people in approximately 30 days). 
This festival is held every two years with approximately ten million people converging on the place over a period of four days. The data is collected using video graphic survey. Video graphic data had been collected for four hours under normal weather condition. Video extraction was done for 9000 frames, and 2200 samples were collected from both the locations. Gender (Male and Female), age group (Child, Young, Middle and Elder), group size (2 and 3+ more), child holding $(\mathrm{CH})$, child carrying $(\mathrm{CC})$ and people with and without luggage affect the speed of the crowd. The number of samples collected for the group size is 200, whereas for the gender, age, people with and without luggage is 1600. Also, the number of samples obtained for the child carrying and child holding is 400. Various parameters extracted from the video include people count, density, speed of the individual persons, tracking of individual persons and flow.

\section{Methodology}

The methodology includes suitable site selection for the field survey, collection, and extraction of field data, density estimation, and identification of factors affecting the crowd behaviour, speed and flow estimation, thereby analysing the effect of crowd behaviour. The collected video is played in the lab and the details of data extraction are presented in detail in the subsequent sections. The data analysis is followed by statistical testing, regression modelling and validation. Fig. 1 depicts the detailed methodology for the crowd behaviour analysis.

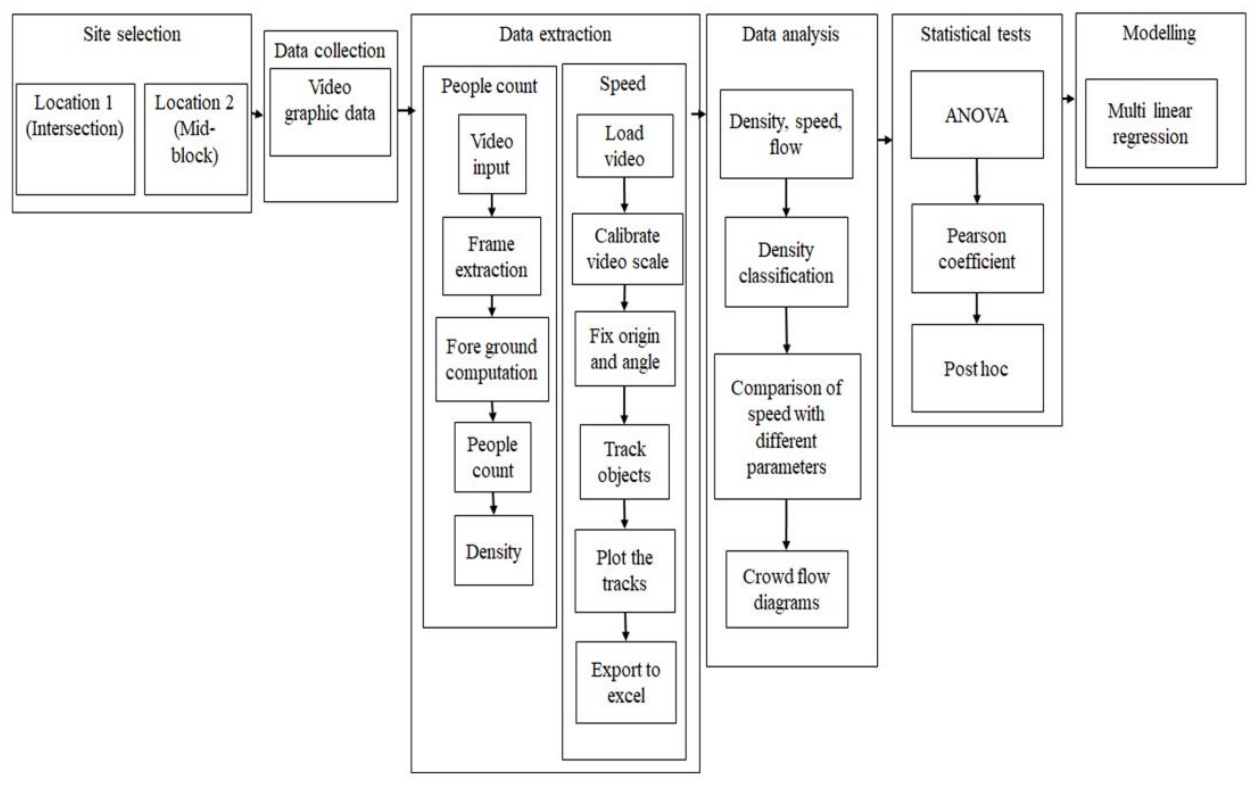

Fig.1 Flow diagram for methodology 
Crowd behavioural analysis at a mass gathering event Analiza zachowań thumu w masowych zgromadzeniach

\section{Crowd Density Estimation}

For estimation of the crowd density, background subtraction technique was used. Background subtraction approach is broadly used for detecting moving objects in videos from still cameras. The moving objects detected based on difference between the current frame and reference frame (background image). First video is imported to MATLAB for frame extraction.

Then current frame is converted from RGB to gray, and the images are compared to find the difference. Later the image is converted into binary and blobs in the image are opened. BLOB stand for Binary Large Objects and it is used to represent a group of pixels having similar values for intensity but different from the ones surrounding it. The number of blobs in the image is the people count. The ratio of the crowd count to the area gives the crowd density. Fig. 2 shows the flow diagram for estimating the density of crowd. Fig. 3 shows the original, and background subtracted images to estimate the density.

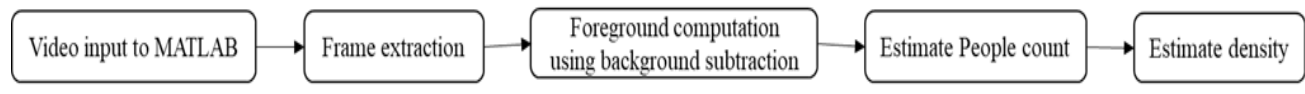

Fig. 2 Crowd density estimation flow chart

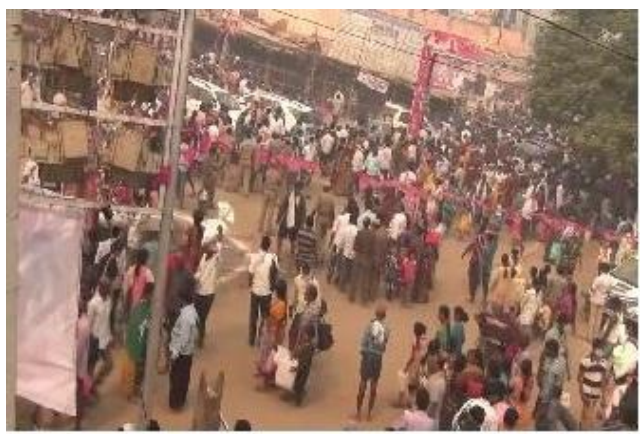

(a) Original frame

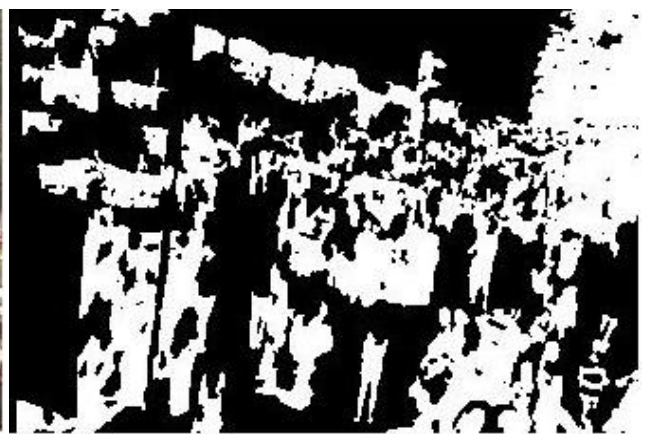

(b) Background subtracted image

Fig. 3 Sample density estimation by using back ground subtraction (sample).

\section{Crowd Tracking}

In crowd analysis, another task is tracking the people, which include identifying the position of the same person in a sequence of frames. Fig. 4 shows the image tracking the persons in the frame at L1. For analysis, tracker software is used where the persons are tracked manually as well as automatically to find the position, velocity, and acceleration. 


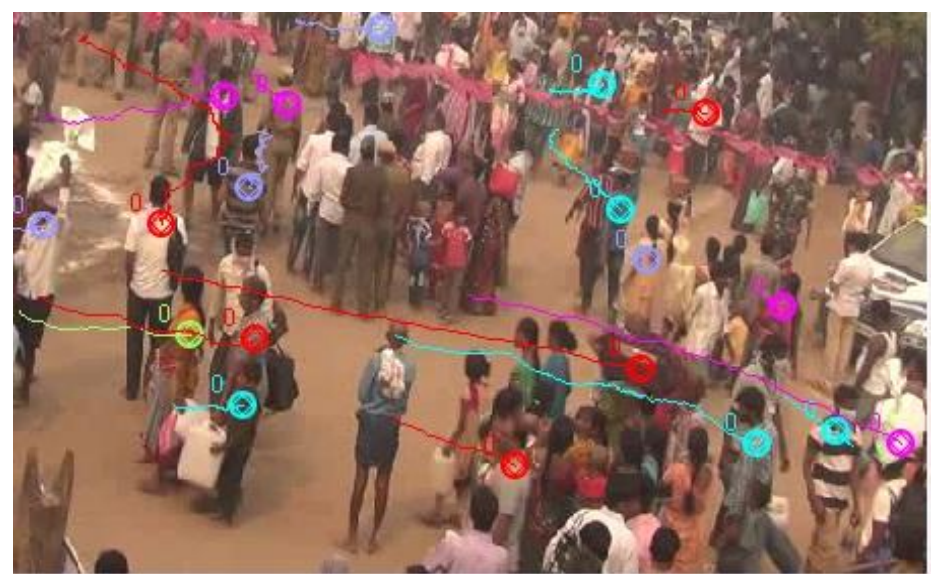

Fig. 4 Images representing the sample tracking of persons in the frame

For the extraction of speed, the video is imported into the tracker software, where the tracker automatically converts video into frames. After converting into frames, the coordinate axis needs to be fixed and the point mass is to be created. Subsequently, when persons in the crowd are selected manually, the coordinates, speed of the selected person are observed automatically. The pixel coordinates obtained from the video cannot represent person movements in real-world situations because of the camera angle was not perpendicular to the ground. Hence conversion of pixel coordinates to real-world coordinates was required for getting the real world trajectories of individuals. A direct linear conversion algorithm was applied based on Wolf and Dewitt (2000) to minimize the effect of swaying and height difference. The lower left corner of the video image selected as the coordinate origin, the relevant conversion formulas are as follows (Eqs. (1) and (2)):

$$
\begin{aligned}
& u+\frac{L_{1} x+L_{2} y+L_{3}}{L_{7} x+L_{8} y+1}=0 \\
& v+\frac{L_{4} x+L_{5} y+L_{6}}{L_{7} x+L_{8} y+1}=0
\end{aligned}
$$

Where $(\mathrm{u}, \mathrm{v})$ are the pixel coordinate, $(\mathrm{x}, \mathrm{y})$ are the real world coordinate and $\mathrm{L}_{1}-\mathrm{L}_{8}$ are transformation coefficients. Eight real world reference points are selected and measured in the experiment sites along with the corresponding pixel coordinates. Four points pairs are used to compute the conversion coefficients and the remaining four are used to check the errors. The following section describes the results and discussions.

\section{Results}

The average crowd density, speed, and flow for both the locations are tabulated in Table 1 . The average crowd density at L1 and L2 observed as 1.73 and $1.58 \mathrm{P} / \mathrm{m}^{2}$ respectively. It is observed L2 has less density compared to L1. 
Crowd behavioural analysis at a mass gathering event Analiza zachowań thumu w masowych zgromadzeniach

Tab. 1 Crowd flow parameters for two locations

\begin{tabular}{|c|c|c|c|c|c|}
\hline Location & $\begin{array}{c}\text { Total } \\
\text { frames }\end{array}$ & $\begin{array}{c}\text { Average people } \\
\text { on each frame }\end{array}$ & $\begin{array}{c}\text { Average } \\
\text { Density }\left(\mathrm{p} / \mathrm{m}^{2}\right)\end{array}$ & $\begin{array}{c}\text { Average } \\
\text { speed }(\mathrm{m} / \mathrm{s})\end{array}$ & $\begin{array}{c}\text { Average flow } \\
(\mathrm{p} / \mathrm{min} / \mathrm{m})\end{array}$ \\
\hline L1 & 4500 & 91 & 1.73 & 0.703 & 73 \\
\hline L2 & 4500 & 79 & 1.58 & 0.931 & 64 \\
\hline
\end{tabular}

\section{Density Classification}

In this study, for the density classification, pedestrian LOS from HCM (2010) was used. In the HCM, average speed, space, flows are mentioned for each LOS. The density and number of people are not indicated. The density is estimated using traffic stream equation $(\mathrm{Q}=\mathrm{KV})$ for the classification. The number of people in each frame was determined by multiplying the area and density. The density and number of persons are calculated by using Pedestrian LOS table. Density classification as per pedestrian LOS tabulated in Table 2.

Crowd density is classified into three categories such as low $(<0.72)$, medium $(0.72$ $-1.64)$ and high (>1.64). Also, based on the number of persons, crowd density is further classified into five categories such as very low $(<0.20)$, low $(0.20-0.45)$, moderate $(0.45-0.72)$, high $(0.72-1.64)$, very high $(>1.64)$.

Tab. 2 Density classification as per pedestrian LOS, HCM (2010)

\begin{tabular}{|c|c|c|c|c|c|c|}
\hline LOS & Speed & $\begin{array}{l}\text { Flow } \\
\text { rate }\end{array}$ & Density & People & $\begin{array}{c}\text { Classification } \\
\text { based on people }\end{array}$ & $\begin{array}{c}\text { Classification } \\
\text { based on density }\end{array}$ \\
\hline A & $\leq 1.32$ & $\leq 16$ & 0.20 & 10 & Very low & \multirow{4}{*}{ Low } \\
\hline B & $1.27-1.32$ & $16-23$ & 0.30 & $10-14$ & \multirow{2}{*}{ Low } & \\
\hline $\mathrm{C}$ & $1.22-1.27$ & $23-33$ & 0.45 & $14-22$ & & \\
\hline $\mathrm{D}$ & $1.14-1.22$ & $33-49$ & 0.72 & $22-35$ & moderate & \\
\hline $\mathrm{E}$ & $0.76-1.14$ & $49-75$ & 1.64 & $35-80$ & high & Medium \\
\hline $\mathrm{F}$ & $\leq 0.76$ & Var. & $>1.64$ & $>80$ & Very high & High \\
\hline
\end{tabular}

The comparison was done for the density values obtained from the present study with the previous studies and is tabulated in Table 3 and 4 . There are minor variations in the classification with respect to density in the present study and this has been adopted for further analysis. The average density observed at L1 is 1.73 $\mathrm{P} / \mathrm{m} 2$ which fall into level of service $\mathrm{F}$. Level of service $\mathrm{F}$, the speed is given as $\leq$ 0.76 and observed speed is $0.703 \mathrm{~m} / \mathrm{sec}$. 
Tab. 3 Comparison of density classification based on people count with other related work

\begin{tabular}{|l|c|c|c|c|}
\hline \multirow{3}{*}{ Density } & \multicolumn{4}{|c|}{ Number of people } \\
\cline { 2 - 5 } & $\begin{array}{c}\text { Marana et al. } \\
(1998)\end{array}$ & $\begin{array}{c}\text { Jiang et al. } \\
(2014)\end{array}$ & Ramalan et al. & Present study \\
\hline Very low & $0-20$ & $0-10$ & $<7$ & $0-10$ \\
\hline Low & $21-40$ & $11-30$ & $7-10$ & $10-22$ \\
\hline Moderate & $41-60$ & $31-60$ & $11-16$ & $22-35$ \\
\hline High & $61-80$ & $61-100$ & $17-26$ & $35-80$ \\
\hline Very high & $>80$ & $>100$ & $>26$ & $>80$ \\
\hline
\end{tabular}

Tab. 4 Comparison of density

\begin{tabular}{|l|c|c|c|}
\hline \multirow{2}{*}{\multicolumn{1}{c|}{ Reference }} & \multicolumn{3}{c|}{ Density $\left(\mathrm{P} / \mathrm{m}^{2}\right)$} \\
\cline { 2 - 4 } & Low & Medium & High \\
\hline Meynberg et al. (2016) & $0.2-0.5$ & $0.5-1.5$ & $>1.5$ \\
\hline Jacobs method & 1.07 & 2.4 & 4.3 \\
\hline Hong Bao et al & $<0.6$ & $0.6-2.0$ & $>2.0$ \\
\hline Present study & $<0.72$ & $0.72-1.64$ & $>1.64$ \\
\hline
\end{tabular}

The flow for the level of service $\mathrm{F}$ is given as greater than $80 \mathrm{P} / \mathrm{min} / \mathrm{m}$, but the observed flow is $73 \mathrm{P} / \mathrm{min} / \mathrm{m}$. The lesser flow values can be attributed to the fact that factors like age, gender, group size, $\mathrm{CC}, \mathrm{CH}$, people with luggage and without luggage affect the movement of people in the crowd. Further analysis was carried out at L1 to explore the effect of above mentioned factors on speed.

\section{Speed Comparison}

Fig. 5 and Fig. 6 represents the comparison of crowd speed for two locations with respect to gender, age, group size, $\mathrm{CC}, \mathrm{CH}$, people with luggage and without luggage.

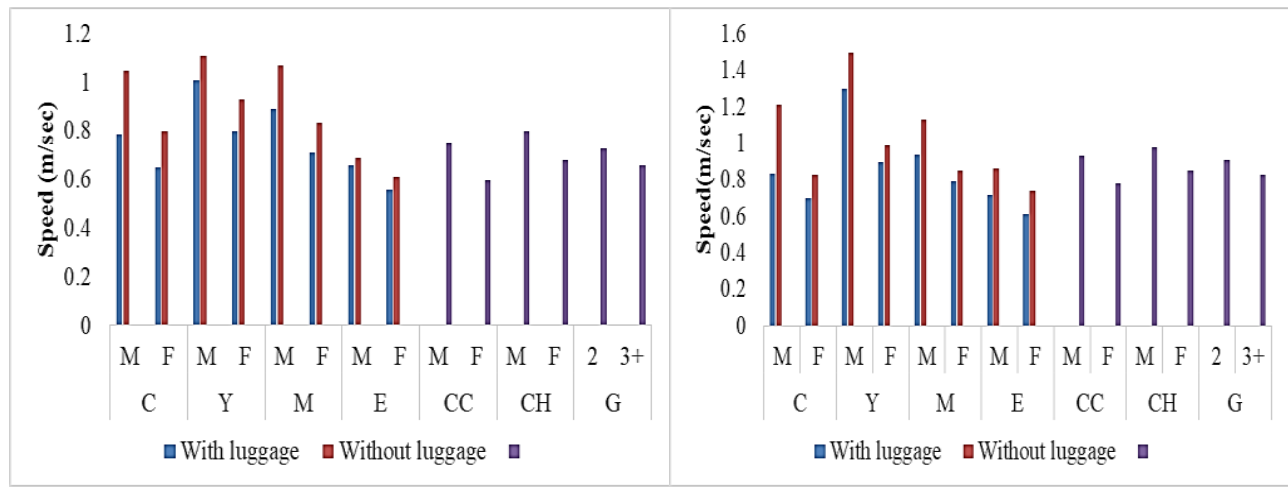

Fig. 5 Speed of crowd movement at L1 Fig. 6 Speed of crowd movement at L2

Note: (Male (M). Female $(F)$. Child $(C)$, Young $(Y)$. Middle age $(M)$.

Elder (E). Child Carrying (CC). Child Holding $(C H)$. Group $(G)$.

Two members (2). Three + more (3+)) 
Crowd behavioural analysis at a mass gathering event Analiza zachowań thumu w masowych zgromadzeniach

The average speed of younger male pedestrian without luggage was high as compared to other pedestrians. The average speed of the $\mathrm{CH}$ and $\mathrm{CC}$ of the male pedestrian was high compared to a female pedestrian. The speed of three or more persons in a group was low compared to single and paired persons, this is due to the reason that people move by guiding two persons at two ends.

\section{Fundamental Diagrams of Crowd Flow}

From the Fig. 7 (a), speed of the crowd was low at L1 compared to L2, because density was high at L1. From Fig. 7 (b) and 7 (c), maximum flows for L1 and L2 was observed to be $135 \mathrm{p} / \mathrm{min} / \mathrm{m}$ and $102 \mathrm{p} / \mathrm{min} / \mathrm{m}$.

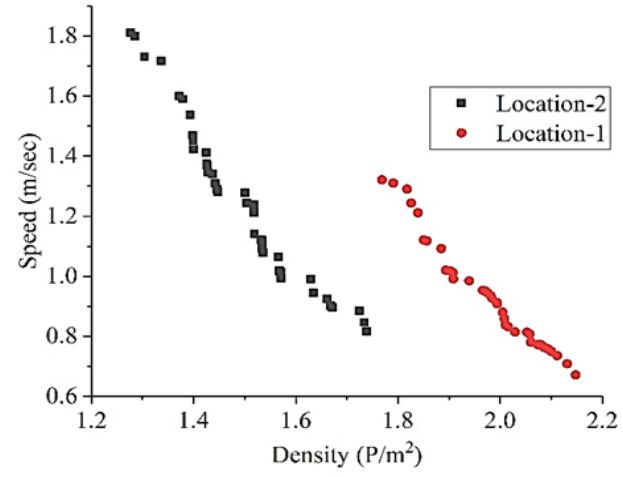

(a) Speed-Density relationship

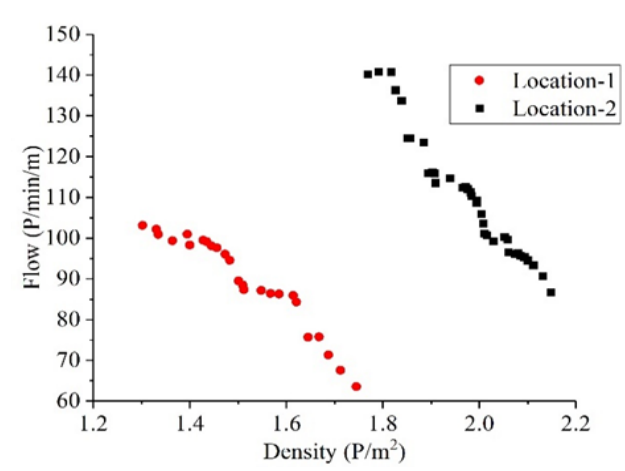

(b) Flow-Density relationship

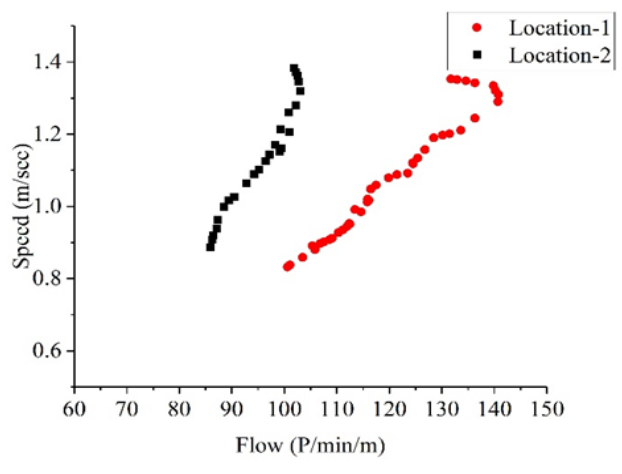

(c) Speed-Flow relationship

Fig. 7 Speed, Density and Flow relationships for the two locations

\section{Statistical Tests}

For statistical analysis, ANOVA and Pearson correlation tests were performed using SPSS and variables considered for analyses were gender, age group, group size, $\mathrm{CH}, \mathrm{CC}$ and person with luggage and without luggage factors. Gender was divided into two categories, and the values were assumed as 0 for male pedestrian and 1 for female pedestrian. Age was divided into four categories, and the values were considered as 0 for the child, 1 for younger, 2 for middle age, and 3 for older. 
The values assumed as 0 for people without luggage and 1 for people with luggage. $\mathrm{CH}$ was divided into two categories, and the values were considered as 0 for not holding children and 1 for holding children. $\mathrm{CC}$ was divided into two categories, and the values were assumed as 0 for not carrying children and 1 for carrying children. Group size was divided into three categories, 0 for single, 1 for pair and 2 for more than three persons. All tests are performed at 95\% confidence level. From Tables 5 and 6 , it can be said that person gender, age, group size and luggage factors have a significant effect on pedestrian walking speed. From Table 5 the $\mathrm{F}$ value is greater than the Table value (3.842), and $\mathrm{P}$ value is less than the 0.05 for all factors.

Pearson correlation coefficient value range between -1 and +1 . Where -1 shows total negative correlation, 0 is nonlinear correlation and +1 shows total positive correlation. Pearson correlation coefficients were found to be negative linear correlation were for factors gender, age, and luggage. A nonlinear correlation was observed for $\mathrm{CC}$, Group and $\mathrm{CH}$ with respect to speed.

\section{Tab. 5 Statistical tests for crowd movement}

\begin{tabular}{|l|c|c|c|c|c|}
\hline \multirow{2}{*}{ Factor } & \multicolumn{2}{c|}{ ANOVA } & \multicolumn{2}{c|}{ Pearson coefficient } & \multirow{2}{*}{ Remarks } \\
\cline { 2 - 5 } & F & P value & Coefficient & P value & \multirow{2}{*}{ Significant } \\
\hline Gender & 191.111 & 0.000 & -0.527 & 0.000 & Significant \\
\hline Age & 53.963 & 0.000 & -0.328 & 0.000 & Sigifan \\
\hline Luggage & 68.193 & 0.000 & -0.333 & 0.00 & Significant \\
\hline CC & 2.759 & 0.0972 & -0.071 & 0.0972 & Not significant \\
\hline CH & 0.905 & 0.342 & 0.041 & 0.342 & Not significant \\
\hline Group & 1.097 & 0.312 & -0.034 & 0.540 & Not significant \\
\hline Density & 16.041 & 0.000 & -0.163 & 0.0218 & Significant \\
\hline
\end{tabular}

For density, there was a significant effect on speed atL1as the $\mathrm{p}$ value was found to be $<0.05$. Person gender had the significant effect on the speed of the crowd. The male person speed was 1.23 times more compared to female pedestrian speed. It was observed that younger pedestrians have the fastest speed compared to others. Person without luggage was 1.2 times more speed compared to with luggage.

\section{Multiple Linear Regression Analysis}

The general form of the linear regression model suggested is

$$
\mathrm{B}=\mathrm{A}_{1} \mathrm{X}_{1}+\mathrm{A}_{2} \mathrm{X}_{2}+\ldots+\mathrm{A}_{\mathrm{k}} \mathrm{X}_{\mathrm{K}}+\varepsilon
$$

Where $\mathrm{B}=$ crowd speed, $\mathrm{X} 1=$ gender, $\mathrm{X} 2$ = age, $\mathrm{X} 3$ = luggage, $\mathrm{X}_{4}=$ Density, $\mathrm{A}=$ Parameter, $\varepsilon=$ constant.

For the location under current study, a regression analysis is applied to the crowd movement at L1 as tabulated in Table 6. As negative values of $\beta$ are obtained which will significantly decrease the speed with every increase of the following parameters i.e. children, female, persons with luggage, and density. 
Crowd behavioural analysis at a mass gathering event Analiza zachowań thumu w masowych zgromadzeniach

Pedestrian gender has more effect on speed of the crowd compared to others because the coefficient of gender is more compared to other factors.

Tab. 6 Regression analysis for the crowd speed

\begin{tabular}{|l|c|c|c|}
\hline \multicolumn{1}{|c|}{ Model } & $\beta$ & Standard Error & Significance \\
\hline Constant & 1.171 & 0.015 & 0.000 \\
\hline Gender & -0.242 & 0.012 & 0.000 \\
\hline Age & -0.070 & 0.006 & 0.000 \\
\hline Luggage & -0.179 & 0.014 & 0.000 \\
\hline Density & -0.150 & 0.022 & 0.000 \\
\hline
\end{tabular}

The regression expression is obtained as

Speed $=1.171-0.242 \times$ gender $-0.070 \times$ age $-0.179 \times$ luggage $-0.150 \times$ Density

\section{Validation}

Validation is an important part of modelling which shows that the model is a realistic representation of the actual system. Coefficient of determination, Coefficient of correlation RMSE and MAPE are used for analysing model validation. L1 data is used for the model development and L2 data is used for the model validation. MAPE, RMSE, and $\mathrm{R}^{2}$ values are $1.65,0.15$, and 0.658 obtained for L2 data. It was observed that MAPE values are less than 5\% and RMSE values are less than 0.5. It shows that regression model is best model for the crowd. Fig. 8 represents the scattered plots of expected and observed speed for L2.

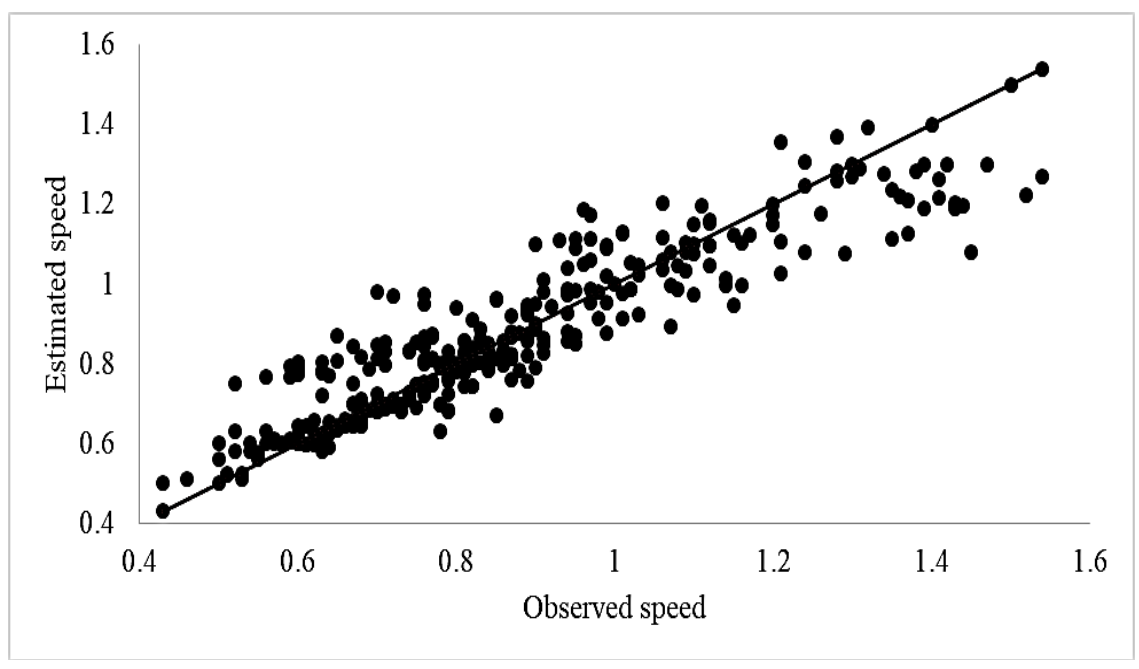

Fig. 8 Observed and expected speed at L2 


\section{Conclusions}

The present study focuses on the individual behaviour of the person in the crowd and the inter-relationship between crowd flow parameters, which can be explained quantitatively using macroscopic flow diagrams. Crowd density was estimated using foreground detection method. It was observed that the average crowd density for location-1 was very high as $1.73 \mathrm{p} / \mathrm{m}^{2}$, whereas for Location-2 it was low as $1.58 \mathrm{p} / \mathrm{m}^{2}$. Based on observations, the estimated crowd density falls in the range > $1.64 \mathrm{p} / \mathrm{m}^{2}$, high-density category. Based on the tracking, it was observed that the average speed of the crowd at location 1 and 2 were found to be $0.803 \mathrm{~m} / \mathrm{s}$ and $0.931 \mathrm{~m} / \mathrm{s}$ respectively. Diversified directional behaviour exists at location L1 whereas directional behaviour is observed in location $\mathrm{L} 2$.

From the traditional q-k-v equation, the average flow for location 1 and 2 was found to be $84.7 \mathrm{p} / \mathrm{min} / \mathrm{m}$ and $68.5 \mathrm{p} / \mathrm{min} / \mathrm{m}$. The walking speed of the male pedestrian was observed to be more than female pedestrian. Also, walking speed of the younger pedestrians was found to be more than other age groups.

The walking speed of people carrying luggage is less compared to people without luggage. From statistical tests, it was concluded that gender, age and luggage factors affecting the pedestrian walking behaviour were found to be significant. MLR model was developed for the modelling of crowd speed using factors considered. The developed model is validated using location 2 data. From the results, it was observed that gender factor had more significant effect on crowd speed when compared to other factors. It was observed that there is a reduction in the speed as the proportion of the female pedestrian increases. Crowd stampedes occur when huge number of people move in a small areas. Crowd speed is low when density is more which leads to congestion leading to unforeseen standstill and panic situation. This behaviour study is applicable in crowd management to avoid crowd disasters and assure public safety and to provide guidelines for the design of public spaces. Crowd simulations are used to replicate the existing ground conditions and thereby create virtual environments for efficient planning and management of crowd evacuation under unforeseen situations. This study helps in proper dispersal of crowd in a planned manner to that of diversified directional flow that exist during crowd gathering events.

\section{References}

[1] Ali, S., M. Shah., 2007. A lagrangian particle dynamics approach for crowd flow segmentation and stability analysis. In Proc. IEEE Conf. Computer Vision and Pattern Recognition, pp. 1-6

[2] Andrade, E.L., Blunsden, S., Fisher, R.B., 2006. Modelling crowd scenes for event detection. In Proc. Int. Conf. Pattern Recognition, Washington, DC, pp. $175-178$ 
Crowd behavioural analysis at a mass gathering event Analiza zachowań thumu w masowych zgromadzeniach

[3] Boghossian, B.A., Velastin, S.A., 1999. Motion-based machine vision technique for the management of large crowds. In Proc. 6th IEEE Int. Conf. Electronics, Circuits and Systems, vol. 2, pp. 961-964

[4] Brostow, G.J., Cipolla, R., 2006. Unsupervised Bayesian detection of independent motion in crowds. In Proc. IEEE Conf. Computer Vision and Pattern Recognition, Washington, DC, pp. 594-601

[5] Chan, A., Liang, Z., Vasconcelos, N., 2008. Privacy preserving crowd monitoring: Counting people without people models or tracking. In Proc. IEEE Conf. Computer Vision and Pattern Recognition, 2008, pp. 1-7

[6] Cheriyadat, A.M., Radke, R., 2008. Detecting dominant motions in dense crowds. In IEEE J. Select. Topics Signal Process. vol. 2, no. 4, pp. 568-581

[7] Davies, A.C., Yin, J.H., Velastin, S.A., 1995. Crowd monitoring using image processing. IEE Electron. Commun. Eng. J., vol. 7, no. 1, pp. 37-47

[8] Dridi, M.H., 2009. Tracking Individual Targets in High Density Crowd Scenes Analysis of a Video Recording in Hajj. In Current Urban Studies, 3, 35-53

[9] Faisel, T., Shibu, I., Pradeep kumar, K.M., Keshav Mohan, A.P., 2013. Human stampedes during religiousfestivals: A comparative review of mass gathering emergencies in India. International Journal of Disaster Risk Reduction, 5, 10-18

[10] Gayathri, H., Aparna, P.M., Ashish Verma, 2017. A review of studies on understanding crowd dynamics in the context of crowd safety in mass religious gatherings. International Journal of Disaster Risk Reduction, 25, 82-91

[11] Hong Bao., Wang, B., Yang, S., Lou, H., 2013. Crowd Density Estimation Based on Texture Feature Extraction. In journal of multimedia, vol. 8, no. 4

[12] http://www.opensourcephysics.org/items/detail.cfm?ID=7365, Tracker video analysis and modelling tool

[13] Jacobs, H., (1967). To count a crowd. Columbia Journalism Review 6, 36-40

[14] Jacques, J.C.S.Jr., Braun, A., Soldera, J., Musse, S.R., Jung, C.R., 2007. "Understanding people motion in video sequences using voronoi diagrams". In Pattern Anal. Applicat., vol. 10, no. 4, pp. 321-332

[15] Jiang, M., Huang, J., Wang, X., Tang, J., Wu, C., 2014. An Approach for Crowd Density and Crowd Size Estimation." In journal of software, vol. 9, no. 3

[16] Jun, Hu., Lei, You., Juan, Wei., Yangyong, Guo., Ying, Liang., 2014. The pedestrian evacuation model with collision probability in three-dimensional space Transportation Letters Vol. 6, Issue 4, 219-225

[17] Kong, D., Gray, D., Tao, H., 2006. A viewpoint invariant approach for crowd counting. In Proc. Int. Conf. Pattern Recognition, vol. 3, pp. 1187-1190 
[18] Kratz, L., Nishino, K., 2009. Anomaly detection in extremely crowded scenes using spatio-temporal motion pattern models. In Proc. IEEE Conf. Computer Vision and Pattern Recognition, pp. 1446-1453

[19] Leibe, E., Seemann, B., Schiele, B., 2005. Pedestrian detection in crowded scenes. In Proc. IEEE Conf. Computer Vision and Pattern Recognition, Washington, DC, pp. 878-885

[20] Ma, R., Li, L., Huang, W., Tian, Q., 2004. On pixel count based crowd density estimation for visual surveillance. In Proc. IEEE Conf. Cybernetics and Intelligent Systems, vol. 1, pp. 170-173

[21] Marana, A., da Costa, L., Lotufo, R., Velastin, S., 1998. On the efficacy of texture analysis for crowd monitoring. In Proc. Int. Symp. Computer Graphics, Image Processing, and Vision (SIBGRAPI'98), Washington, DC, p. 354

[22] Mehran, R., Oyama, A., Shah, M., 2009. Abnormal crowd behaviour detection using social force model. In Proc. IEEE Conf. Computer Vision and Pattern Recognition, pp. 935942

[23] Meynberg, O., Cui, S., Reinartz, P., 2016. Detection of High-Density Crowds in Aerial Images Using Texture Classification. In Remote Sens. 8, 470

[24] Musse, S. R., Thalmann, D., 1997. A Model of Human Crowd Behaviour: Group Inter Relationship and Collision Detection Analysis. In Computer Animation and Simulations 97, Proc. Euro graphics workshop, Budapest, Springer Verlag, Wien, pp. 39-51

[25] Prasanna Kumar, G., Sumalini, T., 2015. Stampedes are Community Avertible Crowd Disasters. In second world conference on disaster management, Visakhapatnam, Andhra Pradesh, India, 19-22

[26] Rabaud V., Belongie, S., 2006. Counting crowded moving objects. In Proc. IEEE Conf. Computer Vision and Pattern Recognition, pp. 705-711

[27] Rahmalan, H., Nixon, M., Carter, J., 2006. On crowd density estimation for surveillance. In Proc. Institution of Engineering and Technology Conf. Crime and Security, pp. 540-545

[28] Sankaran, M., Lakshmi, S., 2016. Method to determine pedestrian level of service for sidewalks in Indian context. Transportation Letters, Pages 1-8

[29] Wang, X., Ma, X., Grimson, W.E.L., 2009. Unsupervised activity perception in crowded and complicated scenes using hierarchical Bayesian models. In IEEE Trans. Pattern Anal. Machine Intell., vol. 31, no. 3, pp. 539-555

[30] Wolf, P.R., Dewitt, B.A., 2000. Elements of photogrammetry with applications in GIS, Third edition. McGraw Hill 
Crowd behavioural analysis at a mass gathering event Analiza zachowań thumu w masowych zgromadzeniach

[31] Wu, X., Liang, G., Lee, K.K., Xu, Y., 2006. Crowd density estimation using texture analysis and learning. In Proc. IEEE Int. Conf. Robotics and Biomimetics, pp. 214-219

[32] Zhao, T., Nevatia, R., 2003. Bayesian human segmentation in crowded situations. In Proc. IEEE Conf. Computer Vision and Pattern Recognition, vol. 2, pp. 459-466

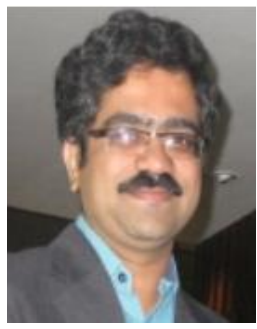

V.R. Ravi Shankar, Kodavanti (born in Tadeppalligudem, Andhra Pradesh, India)

- Scientific Degree: Ph.D.

- University study*: IIT Bombay

- Scientific and university degrees. Publications: 15 Journals and 30 Conference Publications

Fields of research: Crowd dynamic analysis and emergency evacuation planning, Pedestrian behavioural analysis and modelling, Safety Analysis of vehicular interactions in mixed traffic conditions, Non-lane based behaviour modelling and nanoscopic model development, Capacity analysis of highways in mixed traffic conditions.

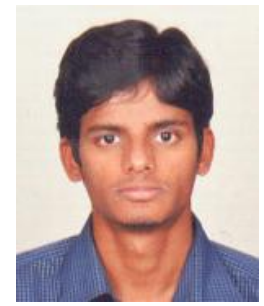

modelling.

Yugendar, Poojari (born in Agapet, Telangana, India)

- Scientific Degree: M.Tech.

-University study*: IIT Delhi

- Scientific and university degrees. Publications: 02 journals and 02 Conference Publications

Fields of research: Crowd dynamic analysis and emergency evacuation planning, pedestrian behavioural analysis and 